\title{
A field study on the physiology of digestion in the Antarctic krill, Euphausia superba, with special regard to chitinolytic enzymes
}

\author{
Friedrich Buchholz and Reinhard Saborowski \\ Institut für Meereskunde, Düsternbrooker Weg 20, D-23105 Kiel, FRG \\ Present address: Biologische Anstalt Helgoland, Marine Station, D-27483 \\ Helgoland, FRG
}

\begin{abstract}
Endo- and exochitinase activities were determined in the stomach and midgut gland of the Antarctic krill, Euphausia superba. along a transect west of the Antarctic Peninsula. Activities were compared with the digestive enzymes protease, cellulase (1,4- $\beta$-D-glucanase) and laminarinase (1,3- $\beta$-D-glucanase). The chlorophyll and protein contents in the surface water of the corresponding stations were determined. Enzyme activities were characterized by high individual and spatial variations. Chitinolytic activity in the stomach correlated well with all digestive enzymes investigated. In the midgut gland, a correlation with cellulase and laminannase was evident. The amount of chlorophyll $a$ and phytoplankton protein in the surface water was not correlated with enzyme activity. Specific enzyme activity was higher in the stomach than in the midgut gland, showing individual ratios for each enzyme. Elevated endochitinase activity in the stomach suggests that chitinous food is digested to oligomers in the stomach. while the subsequent degradation to amino sugars occurs predominantly in the midgut gland.
\end{abstract}

\section{Introduction}

Krill, Euphausia superba, is a key organism in the Antarctic ecosystem. The annual production of krill was estimated by Everson (1977) at 500 million tons. While feeding on phytoplankton, the primary producers, krill act as a food source for top predators. Unlike copepod-dominated food chains, this short krill-dominated food chain is characterized by a strong concentration of biomass at each of the trophic levels (Hempel, 1985). In addition to its significance in Antarctic food chains, krill has an important function in the nutrient flux from the euphotic zone to deeper water layers and the benthos, respectively (Clarke et al., 1988).

Krill are very effective organisms in the Antarctic environment. Accordingly, the physiological characteristics are high growth rates when sufficient food is available, short intermoult periods (Buchholz, 1991) and a generally high energy demand (Kils, 1982). Correspondingly, krill must be able to utilize food efficiently. This also becomes obvious in anatomical and morphological adaptations, e.g. the filtering efficiency of the highly specialized filter basket (Hamner et al., 1983; Kils, 1983). However, effective food utilization also demands physiological adaptations. In this respect, efficient digestive enzymes are required to make nutrients available for gastrointestinal resorption, since digestive enzymes represent the functional link between food uptake and food utilization (Mayzaud et al., 1985).

Corresponding to the preferred food, enzymes are present in the digestive tract of krill that cleave algae-specific substances like the 1,3- $\beta$-D-glucan laminarin and the 1,4-B-D-glucan cellulose (Mayzaud et al., 1985; McConville et al., 1986). In addition, chitinolytic enzymes with high activities are present in the stomach and the midgut gland. Their significance as digestive enzymes was discussed by 
Buchholz (1989). However, our knowledge about the physiology of digestion in Antarctic krill is still limited, particularly concerning the biochemical characteristics of digestive enzymes and mechanisms of enzyme synthesis. A further point of interest for understanding the complex situation in the digestive tract of Antarctic krill is the physiological interaction between the two principal sites of digestion: the stomach and the midgut gland (hepatopancreas).

Since most studies on the physiology of digestion in crustaceans have been carried out on total extracts or in only one digestive organ, we paid special attention to the determination of digestive enzyme activities in the stomach and the midgut gland, separately. In order to establish whether chitinolytic enzymes are relevant to digestive processes, we measured the activities of endochitinase (poly- $\beta$-1,4-(2-acetamido-2-deoxy)-D-glucosid-glucanohydrolase) and exochitinase ( $\mathrm{N}$-acetyl- $\beta$-D-glucosaminidase, NAGase). The activity patterns were compared with those of protease, cellulase and laminarinase by correlation analysis. Furthermore, the amount of chlorophyll (chl) $a$ as well as the protein content of plankton at the sampling sites were related to the enzyme activities in the krill's digestive organs.

\section{Method}

\section{Krill and phytoplankton samples}

Antarctic krill, Esuperba, were caught with a Rectangular Midwater Trawl, RMT $1+8$ (Roe and Shale, 1979) during the cruise Met 11/4 (21 December 1989-18 January 1990) of the research vessel FS 'Meteor' west of the Antarctic Peninsula (Figure 1). Sampling was carried out in three depth horizons (Siegel, 1992). Samples for our investigations were obtained from the upper horizon $(60 \mathrm{~m}$ to surface). Immediately after the catch, krill were frozen and stored at $-75^{\circ} \mathrm{C}$ until analysis.

Phytoplankton were obtained from the same stations as the krill catches (Figure 1). Surface water (140-7501) was filtered through $3 \mu \mathrm{m}$ membrane filters (Sartorius, 11302-293-G) with a pressure filtration system (Sartorius, SM 16277). The filters were frozen and stored at $-75^{\circ} \mathrm{C}$ until analysis.

\section{Morphometric data and colour index of the digestive organs}

The lengths and fresh weights of thawed animals were measured, and the sex was determined according to Makarov and Denys (1980). Animals with no distinct sexual differentiation were classified as juveniles.

The fullness of the stomach, the midgut gland and the gut was determined visually using a colour index according to Morris et al. (1983).

\section{Dissection and homogenization}

The stomach and hepatopancreas were dissected from frozen animals. Homogenization of the organs was carried out in a total volume of $1 \mathrm{ml} 0.2 \mathrm{M}$ citrate/phosphate buffer (CPB) (pH 5.5) on ice with an ultrasonicator (Branson, Sonofier B-12, microtip 101-148-063) at 30\% of maximal energy for $3 \times 15 \mathrm{~s}$, interrupted by a 


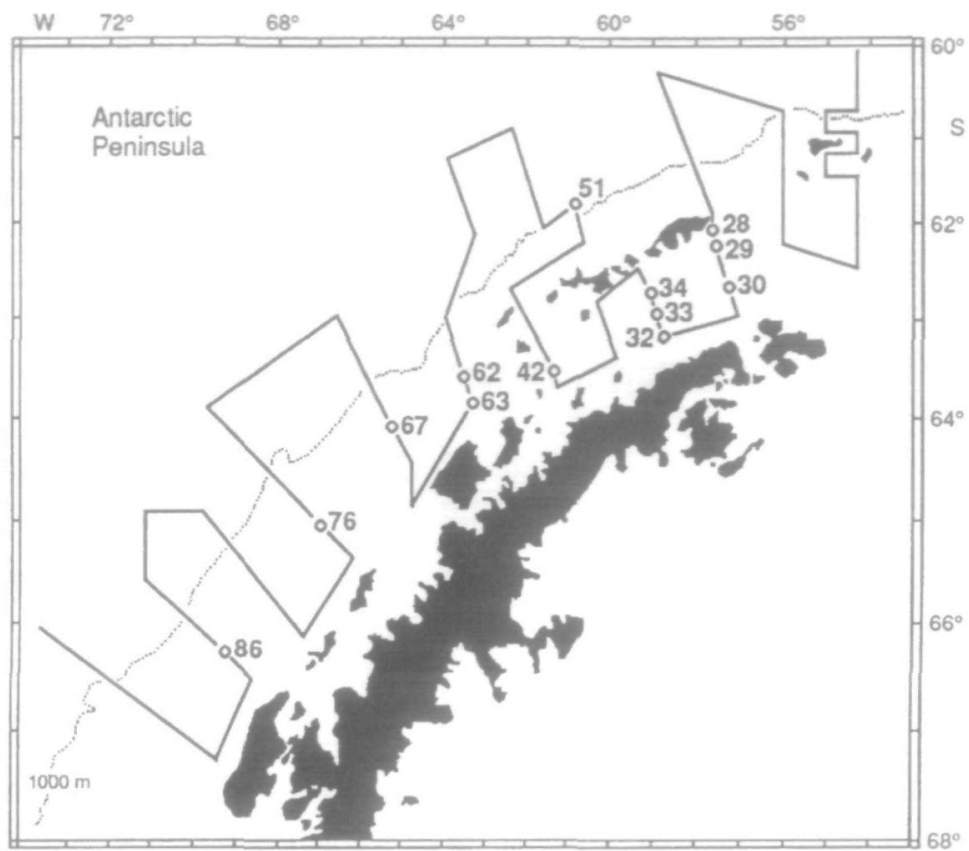

Fig. 1. Station grid of cruise 11/4 of FS 'Meteor'. Only the sampling stations relevant for the present investıgation are marked by numbers.

break of $20 \mathrm{~s}$. The homogenates were centrifuged at $15000 \mathrm{~g}$ and the supernatant was used for biochemical analysis.

\section{Biochemical investigations}

The amount of soluble protein in krill digestive organs was determined after Bradford (1976) with the BioRad dye reagent (Cat. 500-0006). Samples were run in duplicate with parallel bovine serum albumin (BSA) standards.

Protein of phytoplankton samples was determined on homogenates of plankton collected on membrane filters. Pieces of these filters $\left(7.5 \mathrm{~cm}^{2}\right.$ in area) were transferred into reaction tubes and $3 \mathrm{ml}$ of distilled water were added. Homogenization was carried out by ultrasonication (Branson, Sonifier B12) for $3 \times 15 \mathrm{~s}$, interrupted by a break of $20 \mathrm{~s}$ on ice. After continuous shaking (Vortex), $1 \mathrm{ml}$ of the solution was transferred into $1.5 \mathrm{ml}$ reaction tubes (Eppendorf 3810) and centrifuged for 5 min at $15000 \mathrm{~g}$. The amount of protein in the supernatant was also determined according to Bradford (1976): $200 \mu$ l of dye reagent (BioRad) were added to $800 \mu \mathrm{l}$ of sample. BSA standards were run in parallel. Three different pieces of each filter were analysed. Each analysis was performed in duplicate.

Chlorophyll $a$ samples were determined according to Jeffrey and Humphrey (1975). Five millilitres of acetone were added to each piece of filter $\left(20 \mathrm{~cm}^{2}\right)$ in a reaction tube. Chlorophyll $a$ was dissolved by continuous shaking. After centrifuging (15 min at $5200 \mathrm{~g}$ ), the supernatant was measured photometrically. Blanks were run in parallel with clean filters. 
The activity of the endochitinase was determined with CM-Chitin-RBV (No. 04106, Loewe Biochemica, Otterfing, FRG) as substrate (Wolf and Wirth, 1990) and that of the exochitinase NAGase with $p$-nitrophenyl-NAG (Sigma, N 9376) as described by Saborowski et al. (1993). All measurements were run in duplicate with a parallel blank.

The activity of total protease was determined as described by Donachie et al. (1995) using Azocasein-Na-salt as substrate (Serva 14391).

The cellulase (1,4- $\beta$-D-glucanase) activity was determined with the dye-labelled substrate CM-Cellulose-RBB (No. 04100, Loewe Biochemica, Otterfing, FRG). The assay was adapted to $1.5 \mathrm{ml}$ Eppendorf reaction tubes. One hundred microlitres of substrate $(4 \mathrm{mg} / \mathrm{ml})$ were added to $250 \mu \mathrm{l}$ of $0.2 \mathrm{M} \mathrm{CPB}(\mathrm{pH} \mathrm{6.0)}$ and $50 \mu \mathrm{l}$ of sample to start the reaction. After $30 \mathrm{~min}$ incubation at $35^{\circ} \mathrm{C}$, the reaction was stopped by adding $100 \mu \mathrm{l}$ of $1 \mathrm{M} \mathrm{HCl}$. After centrifuging at $15000 \mathrm{~g}$ for $5 \mathrm{~min}$, the absorption of the supernatant was read at $600 \mathrm{~nm}$ against air.

The determination of laminarinase (1,3- $\beta$-D-glucanase) activity was carried out as described for cellulase, except that the substrate was CM-Curdlan-RBB (No. 04107, Loewe Biochemica, Otterfing, FRG) and the reaction was terminated with $2 \mathrm{~N} \mathrm{HCl}$.

\section{Statistics}

Correlation analyses were performed on the data of enzyme activity within the stomach and the midgut gland, as well as amounts of chl $a$ and protein in the water, and enzyme activities in the digestive organs. The strength of the association was expressed by the Pearson correlation coefficients and the Bonferroni-adjusted probabilities. The statistical analysis was carried out with the computer program 'Systat' (Wilkinson, 1989). The significance level was set at $P=0.01$.

\section{Results}

\section{Phytoplankton samples}

The average concentration of chl $a$ at all stations was $0.61 \mathrm{mg} \mathrm{m}^{-3}$. Elevated amounts occurred at stations 28-34 (except at station 29). Low values were observed at stations 42-86 (Figure 2). Stations 28-34 were located in the Bransfield Strait, while the other stations were located in the Drake Passage (see Figure 1).

The protein values were more variable than the chl $a$ values. However, the distribution pattern was similar, except at station 28 . The concentrations ranged from $1.2 \mathrm{mg} \mathrm{m}^{-3}$ at station 63 to $6.9 \mathrm{mg} \mathrm{m}^{-3}$ at station 34 . The protein values correlated well with chl $a$ concentrations $(r=0.897)$.

\section{Morphometric data of krill and colour index of the organs}

The average length of sampled animals was $42.0 \pm 4.5 \mathrm{~mm}$ and the average weight was $561.7 \pm 216.5 \mathrm{mg}$. The largest animals were found at station $51(51.2 \pm 2.9 \mathrm{~mm}$, $1039.0 \pm 140.1 \mathrm{mg}$ ), while the smallest individuals were caught at station $32(35.2 \pm$ $1.5 \mathrm{~mm}, 270.9 \pm 31.0 \mathrm{mg}$ ). The sex distribution was $40 \%$ female and $60 \%$ male. No juveniles were encountered. 


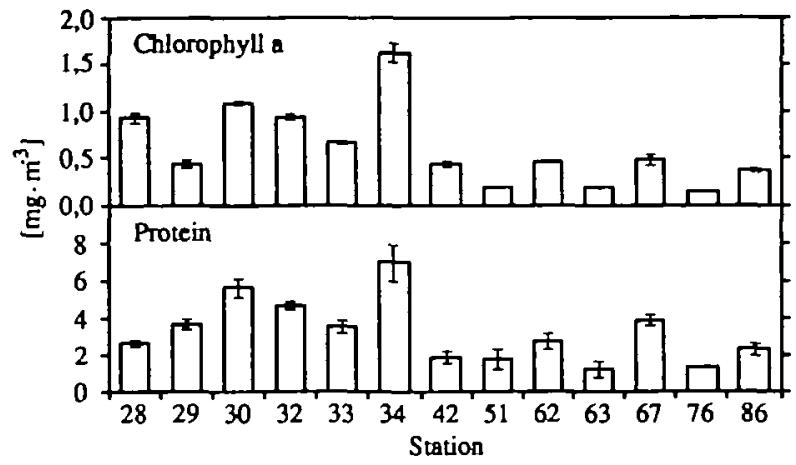

Fig. 2. Chlorophyll $a$ and protein of phytoplankton at the sampling stations (means and SD of three parallel experiments).

Animals at stations $28-42$ had nearly similar colour indices of their stomachs, while greater differences occurred in the colour indices of the midgut and the gut (Figure 3). Animals at station 34 had the highest indices for stomach and hepatopancreas, while the lowest indices in all organs were found at station 51. Stations $51-86$ were characterized by lower indices and greater variability.

\section{Enzyme activity of krill field samples}

Enzyme activities in the krill stomach and midgut gland showed high variability between regions and between individuals. In general, the highest activities of the stomach enzymes investigated were found at station 32 and station 63 (Figures 4 and 5). Furthermore, all enzyme activities increased from station 28 to station 32, indicating a similar relationship of activities of the different enzymes within each station. However, this relationship could not be observed at all stations.

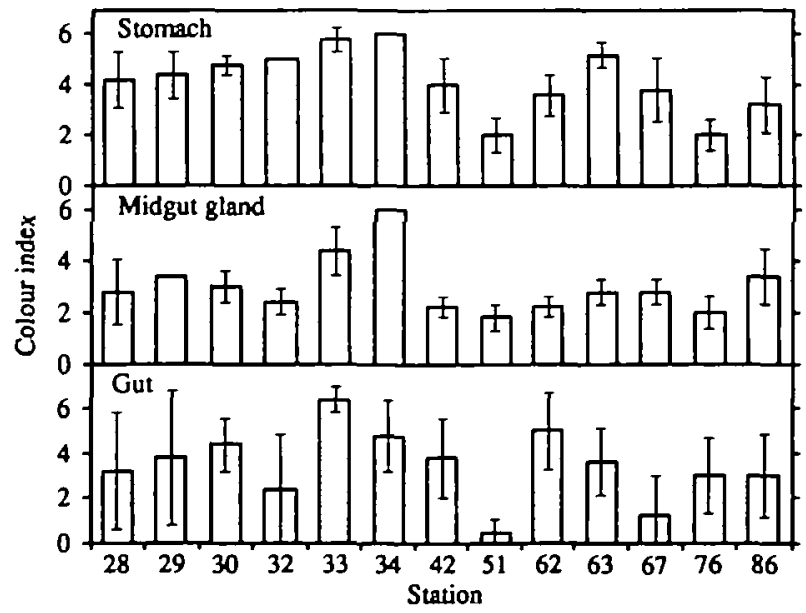

Fig. 3. Colour indices of the digestive organs of Esuperba [means and $95 \%$ confidence interval (CI) $n=5$ ]. 


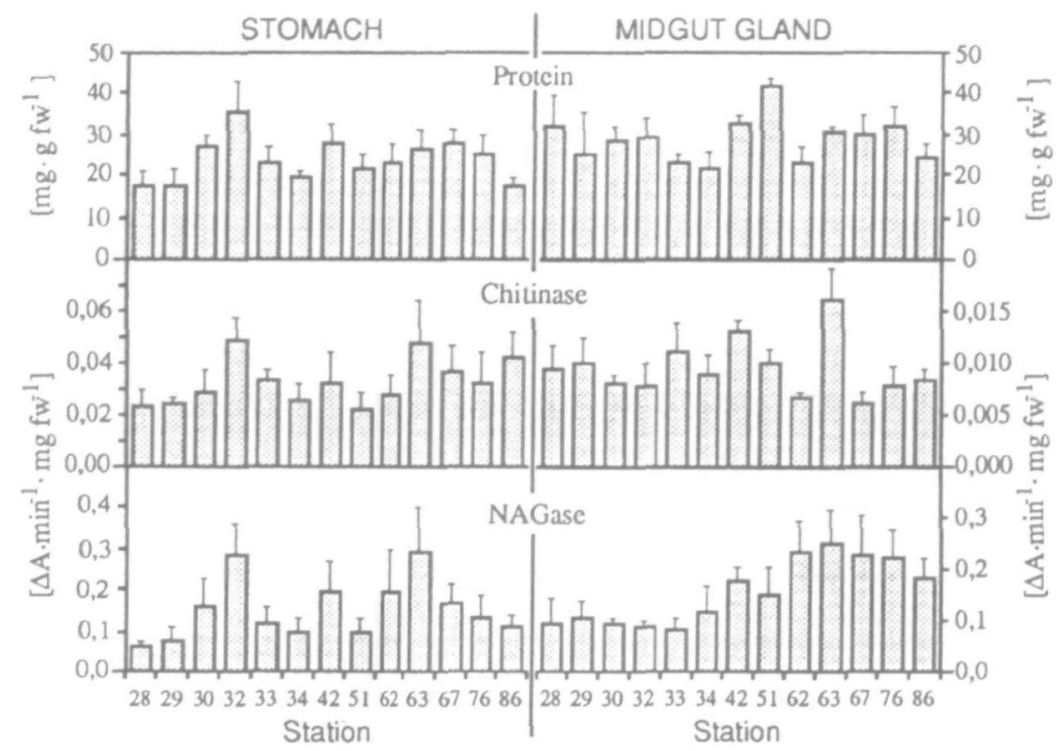

Fig. 4. Soluble protein and chitinolytic enzyme activity of the stomach and the midgut gland of E.superba (means and $95 \%$ CI. $n=5$ ).

In the midgut gland, the enzyme activities showed a similar level of variability as in the stomach. However, the activity pattern was not similar to that of the stomach. The apparently divergent values of chitinase and NAGase over all stations are remarkable.

\section{Correlation analysis}

Enzyme activities in digestive organs. In the stomach, significant correlations were found between all enzymes investigated (Table I), although, in some cases, the correlation coefficients were weak. In the midgut gland, there was a good correlation between chitinase and cellulase, as well as between chitinase and laminarinase, and also between cellulase and laminarinase. No correlation was found between NAGase and other digestive enzymes.

Enzyme activities of the stomach versus activities of the midgut gland. There were only two significant correlations between enzyme activities in the stomach and the midgut gland. Stomach laminarinase was significantly correlated with midgut gland protease $(r=0.508)$ and laminarinase $(r=0.636)$.

Plankton protein, chl $a$ and colour index of the organs versus enzyme activities of digestive organs. In addition to chl $a$ and protein in the surface water, the colour index of the digestive organs was included in the correlation analysis. This index represents the amount of phytoplankton already ingested by the animals. No significant correlations existed between the stomach enzyme activities and either the amount of chl $a$ or the protein content. Only the colour index of the stomach was weakly, but significantly correlated with the laminarinase activity $(r=0.471)$. 


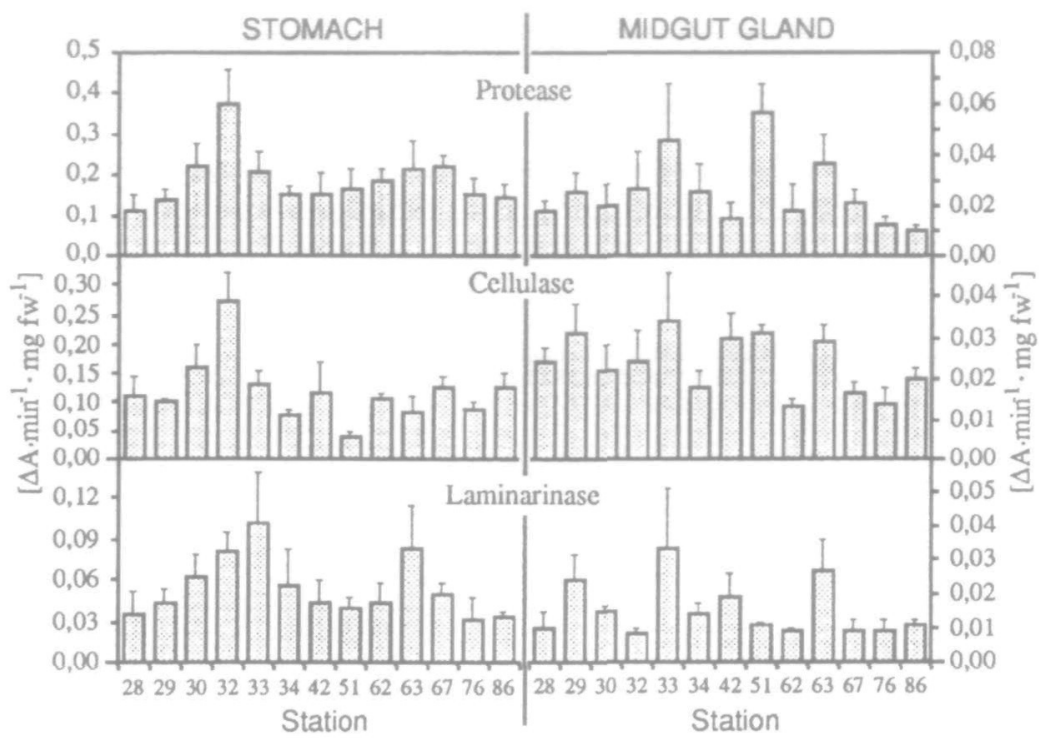

Fig. 5. Digestive enzyme activity in the stomach and the midgut gland of E.superba (means and $95 \% \mathrm{CI}$, $n=5$ ).

In the midgut gland, the colour index was inversely correlated with the protein content of the organ $(r=-0.487)$. Furthermore, there was a significant negative correlation between the chl $a$ content and NAGase activity $(r=-0.477)$.

Chl $a$ and plankton protein versus colour indices. There was a weak correlation between the colour indices of the stomach and the midgut gland and the chl $a$ and plankton protein (Table II), but the colour index for the gut was not correlated with these parameters of the plankton.

\section{Ratio of enzyme activities in the stomach and the midgut gland}

The ratios of enzyme activities in these organs were calculated as the quotient of enzyme activity in the stomach versus the enzyme activity in the midgut gland. The highest ratio occurred for protease $(9.84 \pm 1.45)$ which indicated that the protease activity in the stomach is nearly 10 times higher than that in the midgut gland (Figure 6). High ratios also occurred for cellulase and laminarinase. The chitinase and NAGase had the lowest ratios. The activity of NAGase was only slightly higher in stomach than in the midgut gland. The amount of protein was higher in the midgut gland than in the stomach (ratio $0.86 \pm 0.07$ ).

\section{Discussion}

Chitinolytic enzymes are widely distributed in nature (Jeuniaux, 1966). In arthropods, they are known as moulting enzymes and they also act as digestive enzymes, for example in fish which feed on crustaceans (Danulat, 1986, 1987; Rehbein et al., 1986; Lindsay, 1987). 
Table I. Matrıx of correlation coefficients between the activities of different enzymes in the stomach and the midgut gland of Esuperba

\begin{tabular}{llllcc}
\hline & Chitinase & NAGase & Protease & Cellulase & Laminarinase \\
\hline Stomach & & & & & \\
Protein & $0.648^{*}$ & $0.761^{*}$ & $0.820^{*}$ & $0.691^{*}$ & $0.476^{*}$ \\
Chitinase & - & $0.756^{*}$ & $0.712^{*}$ & $0.636^{*}$ & $0.532^{*}$ \\
NAGase & - & - & $0.719^{*}$ & $0.549^{*}$ & $0.521^{*}$ \\
Protease & - & - & - & $0.856^{*}$ & $0.671^{*}$ \\
Cellulase & - & - & - & $0.548^{*}$ \\
Midgut gland & & & & & \\
Protein & 0.002 & 0.015 & 0.206 & 0.114 & -0.002 \\
Chitinase & - & 0.148 & $0.427^{*}$ & $0.743^{*}$ & $0.701^{*}$ \\
NAGase & - & - & -0.107 & -0.168 & -0.005 \\
Protease & - & - & - & $0.638^{*}$ & $0.451^{*}$ \\
Cellulase & - & - & - & - & $0.734^{*}$ \\
\hline
\end{tabular}

${ }^{*} P<0.01, n=65$.

Buchholz (1989) described the chitinolytic activity in the stomach and midgut gland of the Antarctic krill E.superba and the Northern krill Meganyctiphanes norvegica, and discussed their significance as digestive enzymes. In the present study, we investigated the occurrence of chitinases in the stomach and in the midgut gland of field samples of E.superba and compared the activities with the digestive enzymes protease, cellulase and laminarinase.

Since Antarctic krill are predominantly herbivorous, phytoplankton field samples were used to estimate the food available to the krill. The amounts of chl $a$ and protein were used as a measure of the phytoplankton concentration. For technical reasons, sampling could only be performed in the surface water.

The chl $a$ concentrations (average $0.6 \mathrm{mg} \mathrm{m}^{-3}$ ) were similar to those reported by other authors: Smith and Nelson (1985) found chl $a$ values of $0.25-1.6 \mathrm{mg} \mathrm{m}^{-3}$ in the surface waters of the Ross Sea. Deeper water layers (0-25 m) had only slightly higher amounts of chl $a$. High concentrations occurred in areas of phytoplankton blooms (up to $8 \mathrm{mg} \mathrm{m}^{-3}$ ). El-Sayed and Turner (1977) reported a mean chl $a$ concentration of $0.26 \mathrm{mg} \mathrm{m}^{-3}$ in the surface waters of the Pacific sector of the Antarctic

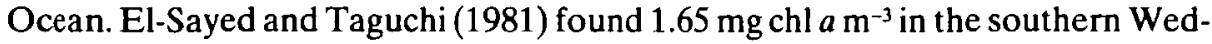
dell Sea. References to phytoplankton protein concentrations in Antarctic waters are given by Mayzaud et al. (1985). The reported amounts are about one order of magnitude higher than those found in our study. This discrepancy can be explained by the differences between the extraction procedures. With our method, we determined the water-soluble protein, which is certainly lower than the $\mathrm{NaOH}$ heat extraction performed by Mayzaud et al. (1985). However, the protein data of our investigations correlated well with the amount of $\operatorname{chl} a(r=0.897)$, indicating that the protein was of phytoplankton origin and thus was available as a food source for krill. In general, chl $a$ and protein values were higher at the stations located in the Bransfield Strait than at those located in the Drake Passage. This could be due to the hydrographic conditions prevailing during the cruise (Stein, 1992).

The activities of the enzymes investigated showed different patterns in the stomach and the midgut gland. In the stomach, significant correlations between 
Table II. Correlation coefficients between chl $a$ and plankton protein and the colour indices of the digestive organs of E.superba

\begin{tabular}{llll}
\hline & \multicolumn{2}{l}{ Colour index } & \\
\cline { 2 - 4 } & Stomach & Midgut gland & Gut \\
\hline Chl $a$ & $0.579^{*}$ & $0.595^{*}$ & 0.247 \\
& $0.539^{*}$ & $0.589^{*}$ & 0.120 \\
\hline
\end{tabular}

$* P<0.01, n=65$.

chitinase and protease, as well as between protease and cellulase, occurred, but there was no correlation between cellulase and laminarinase or between chitinase and laminarinase. Similar differences in correlation analysis of digestive enzymes in E.superba were reported by Mayzaud et al. (1985) for the enzymes amylase, laminarinase, cellulase, $\beta$-galactosidase and trypsin. The results of our field investigations indicate a selective availability of digestive enzyme activity. If enzymes were always present in similar proportion to one another, significant relationships should exist. Statistical relationships between the nutrients carbohydrate and protein, chlorophyll and the digestive enzymes amylase, maltase, cellubiase, lactase, trehalase as well as acid and alkaline phosphatase were reported by Mayzaud and Conover (1975). The investigations were performed on zooplankton total samples, dominated by the copepods Calanus minutus, Acartia clausi and Temora longicornis. Corresponding investigations by Mayzaud et al. (1985) on E.superba did not give similar results, and our results also did not show correlations between chl $a$ or protein values and enzyme activities. The chemical components of phytoplankton at only one depth are probably not fully representative of the resources available to the krill. Mayzaud et al. (1985) investigated the phytoplankton at $15 \mathrm{~m}$ depth and we did so in the surface water.

Furthermore, misinterpretations are likely because of the high mobility and filtering efficiency of krill: in contrast to relatively small copepods, E.superba is characterized by a much higher mobility and filtering efficiency. Phytoplankton can thus be depleted rapidly and effectively by krill swarms. Consequently, determining the potential food in the water may lead to underestimations at high graz-

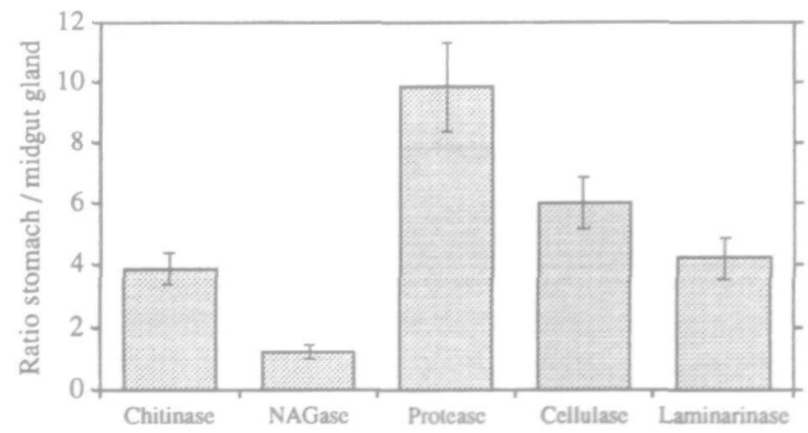

Fig. 6. Ratios of enzyme activities between the stomach and midgut gland of E.superba (means and $95 \%$ $\mathrm{CI}, n=65)$. 
ing activity of krill. This could explain the lack of correlation between amounts of food and digestive enzyme activity reported above. Krill are also fast swimmers and can leave grazed areas rapidly. Therefore, we cannot be sure that krill caught in a certain area were also feeding there. A more appropriate estimate of the amount of food ingested by E.superba may be the colour index of the digestive organs. However, the correlation analysis of the colour index with the digestive enzyme activity showed a significant relationship only in the case of laminarinase, while no significant correlation was found between the colour index and the other enzymes investigated. Based on these results, it can be suggested that laminarin (or generally 1,3-B-D-glucan) was the main component of the phytoplankton ingested by the krill and that the corresponding enzyme activity was induced as postulated by Mayzaud and Mayzaud (1981).

The activities of all the enzymes investigated were higher in the stomach than in the midgut gland, especially for protease which showed activities nearly 10 times higher in the stomach. This effect could be explained by a higher concentration of enzymes in this organ. Enzymes are synthesized in the midgut gland and released into the stomach, where they occur in a relatively high quantity compared to the midgut gland. Furthermore, expressing enzyme activity per unit fresh weight leads inevitably to a high result for the stomach, since the stomach contains only the material to be digested and the digestive enzymes, and has a relatively low weight. In contrast, the midgut gland is a more complex organ with a high amount of connective tissue that contributes to the weight and this leads to relatively lower activities than in the stomach.

However, the relationships between the activities of the enzymes investigated in the stomach and the midgut gland should be similar for all enzymes. Since this is not the case, it can be suggested that digestive enzymes are selectively induced or activated in the stomach of E.superba. A stimulation of digestive enzymes was reported by De-La-Ruelle et al. (1992). These authors determined an increase in aminopeptidase activity in the hepatopancreas of the freshwater crayfish Procambarus clarkii following the addition of millimolar quantities of different substances, among them cysteine. Similar mechanisms could operate with the proteolytic enzymes of E.superba and explain the high activities in the stomach compared to the midgut gland.

In the case of the chitinolytic enzymes, the activity of endochitinase is distinctly higher in the stomach than in the midgut gland (stomach:midgut ratio 3:8). In contrast, the activity of exochitinase (NAGase) was nearly equal in both organs (ratio 1:2). These results can be explained by the different biochemical functions of both enzymes. While the endochitinase cleaves chitin to oligomers, NAGase hydrolyses the oligomers to amino sugars. Consequently, the chitinase reaction in the stomach constitutes the first step in chitin digestion. The further degradation to amino sugars takes place in the midgut gland. Similar, but technically more difficult investigations for endo- and exoenzymes of cellulase and laminarinase would provide more information on this point.

The possible contribution of bacteria to digestive enzyme activity cannot be neglected (Especje et al., 1987; Rakusa-Suszczewski and Zdanowski, 1989) particularly for proteases, as shown by Donachie et al. (1995) in the Northern krill, 
M.norvegica. However, we concluded that the digestive enzymes of E.superba are mainly endogenous. It seems unlikely that a population of bacteria big enough to make a significant contribution to enzymes can continuously survive in krill stomachs. Because food is continuously ingested (Antezana et al., 1982) and there is a high turnover rate of food in the stomach, bacteria would be egested through the gut. Furthermore, krill moult frequently every 2-3 weeks during the summer (Buchholz, 1991) and the chitinous cuticule of the stomach is replaced. Therefore, the stomach contents would also be replaced. After each moult, it would take some time for a new bacterial population to become established. If such a population contributed significantly to digestive enzyme activity, a decrease in enzyme activity should be evident after each moult. However, this was not observed in laboratory studies (Buchholz, 1989).

Since Antarctic phytoplankton can be dominated by diatoms that are characterized by the presence of chitinous spines (Johansen and Fryxell, 1985), the ability to digest chitin is obviously significant. In conclusion, our study has confirmed that chitinolytic enzymes in the stomach and midgut gland of field samples of Esuperba are digestive enzymes due to their similar properties compared to other digestive enzymes. In order to satisfy their energy demand, krill are able to utilize a wide range of nutrients.

\section{Acknowledgements}

We thank the staff of the research vessel FS 'Meteor' for excellent support on board. Technical assistance was contributed by Mrs Sonja Böhm and Mr Gerrit Sahling. Constructive comments and discussion was contributed by Dipl. Biol. Gerrit Peters, Dr Ralf-Achim Vetter and Dr Matthew Dring, who also corrected the English. This work was supported by a grant of the German Research Council (DFG Bu 548/2).

\section{References}

Antezana,T., Ray,K. and Melo,C. (1982) Trophic behavior of Euphausia superba Dana in laboratory conditions. Polar Biol., 1, 77-82.

Bradford,M.M. (1976) A rapid and sensitive method for the quantitation of microgram quantities of protein utilizing the principle of protein-dye binding. Anal. Biochem., 72, 248-254.

Buchholz,F. (1989) Moult cycle and seasonal activities of chitinolytic enzymes in the integument and the digestive tract of the Antarctic krill, Euphausia superba. Polar Biol., 9, 311-317.

Buchholz,F. (1991) Moult cycle and growth of Antarctic krill, Euphausia superba, in the laboratory. Mar. Ecol. Prog. Ser., 69, 217-229.

Clarke_A., Quetin,L.B. and Ross,R.M. (1988) Laboratory and field estimates of the rate of faecal pellet production by Antarctic krill, Euphausia superba. Mar. Biol., 98, 557-563.

Danulat,E. (1986) The effects of various diets on chitinase and beta-glucosidase activities and the condition of cod, Gadus morhua (L). J. Fish. Biol., 28, 191-197.

Danulat,E. (1987) Digestibility of chitin in cod, Gadus morhua, in vivo. Helgol. Meeresunters., 41, 425-436.

De-La-Ruelle,M., Hajjou,M., Van-Herp,F. and Le-Gal,Y. (1992) Aminopeptidase activity from the hepatopancreas of Procambarus clarkii. Biochem. Syst. Ecol., 20, 331-337.

Donachie,S., Saborowski,R., Peters,G. and Buchholz,F. (1995) Bacterial digestive enzyme activity in the stomach and hepatopancreas of Meganyctiphanes norvegica (M.Sars, 1857). J. Exp. Mar. Biol. Ecol., 188, 151-165.

El-Sayed,S.Z. and Taguchi,S. (1981) Primary production and standing crop of phytoplankton along the ice-edge in the Weddell Sea. Deep-Sea Res., 28A, 1017-1032. 
El-Sayed.S Z. and TurnerJ.T. (1977) Productivity of the Antarctic and the tropical-subtropical regions: A comparative study. In Dunbar M. (ed.). Polar Oceans. Proceedings of the SCOR/SCAR Polar Oceans Conference. Montreal. 1974. Antarctic Institute of North Amenca. Calgary. pp. 463-503.

Especje.M.E.. Molina.M.G. and Fralle.E.R. (1987) Enzymatic activities of psychrotrophic bacteria from Antarctic krill. BIOMASS Sci. Ser. No. 7. 133-139.

Everson.I. (1977) The living resources of the Southern Ocean. Rome FAO United Nations Development Programme, Southern Ocean Fishenes Survey Programme GLO/SO/77/1. 156 pp.

Hamner,W.M.. Hamner.P.P., Strand.S.W. and GilmerR.W. (1983) Bahavior of Antarctic krill. Euphausia superba: chemoreception, feeding, schooling. and moulting. Science, 220, 433-435.

Hempel.G. (1985) Antarctic marine food weds. In Siegfried.W.R., Condy.P.R. and Laws,R.M. (eds), Antarcuc Nutrient Cycles and Food Webs. Springer-Verlag, Berlin, pp. 266-270.

Jeffrey.S.W. and Humphrey,G.F. (1975) New spectrophotometric equations for determining chlorophyll a, b, cl and $\mathrm{c} 2$ in higher plants, algae and natural phytoplankton. Blochem. Physiol. Pflanzen. 167. 191-194.

Jeuniaux.C. (1966) Chitinases. Methods Enzymol., 8, 644-650.

Johansen, J. and Fryxell,G A. (1985) The genus Thalassiosira (Bacillariophyceae): Studies on species occurring south of the Antarctic Convergence Zone. Phycologica, 24, 155-179.

Kils.U. (1982) The swimming behavior. swimming performance and energy balance of Antarctic krill. Euphausia superba. BIOMASS Sct. Ser.. No. 3. 122 pp.

Kils,U. (1983) Swmming and feeding of Antarctic krill, Euphausia superba-some outstanding energetics and dynamics, some unique morphological details. Ber Polarforsch. Sonderh., 4, 130-155.

Lindsay,G.J.H. (1987) Seasonal activities of chitinase and chitobiase in the digestive tract and serum of cod, Gadus morhua (L.). J. Fish. Biol., 30, 495-500.

Makarov,R.R. and Denis,C.J. (1980) Stages of sexual maturity of Euphausia superba. BIOMASS Handbook Ser., 11, 1-11.

Mayzaud.P. and Conover.R.J. (1975) Influence of potential food supply on the activity of digestive enzymes of nentic zooplankton. In Persoone,G. and Jaspers,E. (eds), Proceedings of the 10th European Symposium of Marıne Biology, Ostend, 1975. Universa Press. Wettern. Belgium, Vol. 2, pp. 415-427.

Mayzaud,P. and Mayzaud,O. (1981) Kinetic properties of digestive carbohydrases and proteases of zooplankton. Can.J. Fish. Aquat. Sci., 38, 535-543.

Mayzaud,P., Farber-Lorda J. and Corre,M.C. (1985) Aspects of the nut ritional metabolism of two Antarctic euphausiids: Euphausia superba and Thysanoessa macrura. In Siegfried,W.R., Condy,P.R. and Laws, R.M. (eds), Antarctic Nutrient Cycles and Food Webs. Springer-Verlag. Berlin, pp. 330-338.

McConville,M.J., Ikeda,T., Bacic,A. and Clarke,A.E. (1986) Digested carbohydrases from the hepatopancreas of two antarctic euphausiid species (Euphausia superba and E.crystallorophias). Mar. Biol.. $90,371-378$.

Morris,DJ., Ward,P. and Clarke,A. (1983) Some aspects of feeding in the Antarctic krill, Euphausia superba. Polar Biol., 2. 21-26.

Rakusa-Suszczewski.S. and Zdanowski,M.K. (1989) Bacteria in krill (Euphausia superba Dana) stomach. Acta Protozool. 28. 87-90.

Rehbein.H., Danulat,E. and Leinemann,M. (1986) Activities of chitinase and protease and concentration of fluoride in the digestive tract of Antarctic fishes feeding on krill (Euphausia superba Dana). Comp. Biochem. Physiol., 85A. 545-551.

Roe,H.S.L. and Shale,D.M. (1979) A new multiple rectangular midwater trawl (RMT 1+8M) and some modifications to the Institute of Oceanographic Sciences' RMT 1+8. Mar. Biol., 50, 283-288.

Saborowski,R., Buchholz,F., Vetter,R.-A.H., Wirth,S.J. and Wolf,G.A. (1993) A soluble, dye-labelled chitin derivative adapted for the assay of krill chitinase. Comp. Biochem. Physiol., 1058, 673-678.

Siegel.V. (1992) Assessment of the krill (Euphausia superba) spawning stock off the Antartic Peninsula. Arch. Fischereiwiss., 41, 101-130.

Smith.W.O.Jr and Nelson.D.M. (1985) Phytoplankton biomass near a receding ice-edge in the Ross Sea. In Siegfried,W.R.. Condy,P.R. and Laws, R.M. (eds), Antarctic Nutrient Cycles and Food Webs. Springer-Verlag. Berlin, pp. 70-77.

Stein,M. (1992) Variability of local upwelling off the Antarctic Peninsula, 1986-1990. Arch. Fischereiwiss., 41. 131-158.

Wilkinson.L. (1989) SYSTA T: The System for Statistics. SYSTAT Inc., Evanston, IL. 638 pp.

Wolf,G.A. and Wirth,S.J. (1990) Application of soluble chromogenic substrates for assays of polysaccharide endo-hydrolase activity. In Klement.Z. Rudojph.K. and Sands.D.C. (eds). Methods in Phytobacteriology. Akadémia Kiado. Budapest. pp. 409-413. 